\title{
Economic study of groundwater irrigation system in Lampung Province
}

\author{
Entin A. Karjadi ${ }^{1}$, Andojo Wurjanto ${ }^{1}$, and Devi Ulumit Tias, ${ }^{2 *}$ \\ ${ }^{1}$ Coastal Engineering Research Group, Faculty of Civil and Environmental Engineering, Institut Teknologi Bandung, Bandung, \\ Indonesia \\ ${ }^{2}$ Ocean Engineering Study Program, Faculty of Civil and Environmental Engineering, Institut Teknologi Bandung, Bandung, Indonesia
}

\begin{abstract}
The utilization of groundwater for irrigation purposes in Indonesia, known as Jaringan Irigasi Air Tanah (JIAT), has been developed since 1970 and nowadays they can be found in nearly all region in Indonesia. For example, in Lampung Province, there are 112 JIAT facilities under the authority of the Mesuji Sekampung River Basin Agency. One of the benefits of JIAT is its reliability as it warrants water availability all year long. On the other hand, JIAT operation is costly. Therefore, agricultural irrigation system such as JIAT is less attractive to most farmers unless there is some kind of government subsidy. This paper presents an economic study of JIAT by comparing the benefit for the farmers with the operation cost to determine the feasibility of a JIAT facility. This study is based on the inventory data of JIAT facilities in Lampung Province. The method used in this study is descriptive quantitative. The final result of this study is a recommendation for feasibility requirements for a JIAT facility as a whole, which can be used by River Basin Agencies (BWS/BBWS) in Indonesia as a guideline to determine the feasibility and sustainability of a JIAT facility.
\end{abstract}

\section{Background}

JIAT is an agricultural irrigation system, especially for areas not covered by surface irrigation. The purpose of JIAT development is to help the farmers increase harvest production capacity without constraining water availability.

JIAT has been developed since 1970 and nowadays they can be found in nearly all region in Indonesia. in Lampung Province, there are 112 (one hundred and twelve) JIAT facilities under the authority of the Mesuji Sekampung River Basin Agency (Balai Besar Wilayah Sungai Mesuji Sekampung = BBWS MS). In accordance to national regulations, the government is obliged to carry out development and also maintenance of the JIAT infrastructure. Whereas water-use farmers, it is advisable to finance their own operating costs after the first 2 years of infrastructure completion.

In fact, the existence of JIAT infrastructure does help to overcome water scarcity in the dry season, so farmers can still irrigate their fields by relying on water from JIAT. However, JIAT's operating costs are not cheap, ranging from fuel expenditures to wages for JIAT operators. This will be worsten if the infrastructure performance conditions are not good, so operating costs are higher and conversely the benefits received by farmers are lower.
The purpose of this study was to calculate the economic feasibility of JIAT from the side of farmers and government.

\section{Location of study}

Study locations are 112 JIAT spread in Lampung Province, there are 7 JIAT locations in Tulang Bawang, 5 locations in Way Kanan, 7 locations in East Lampung, 3 locations in Pringsewu, 31 locations in Central Lampung, 57 locations in South Lampung, and 2 locations in Pesawaran District.

\section{Method}

This study is based on the inventory data of JIAT facilities in Lampung Province. The method used in this study is descriptive quantitative, which comprises of several steps, i.e., conducting (1) collaborative efforts with BBWS MS on collecting updated data of JIAT in 112 locations, which consist of data on physical and functional conditions of JIAT infrastructures, crop productivities, personnel organizations, all documented information, and the Groundwater User Farmers Association; (2) analysis of JIAT performances based on available data and Government Regulation of Ministry of Public Works and Public Housing Regulation Number 12/RT/M2015

\footnotetext{
Corresponding author: ulumit_d@yahoo.co.id
} 
regarding Exploitation and Maintenance of Irrigation System; (3) analysis of the actual cost for Operation and Maintenance $(\mathrm{O} \& \mathrm{M})$ for each JIAT facility, namely AKNOP; (4) data collection of JIAT benefits for the farmers through questionnaire and interviews with the farmers; (5) economic analysis based on benefit and operation cost, so the economic feasibility of JIAT system in Lampung Province can be determined.

\subsection{Inventory of secondary data}

Secondary data are summarized in the technical tables. For example, Table 1 is show one data in SBP71, it is one of location of JIAT in Sidoreno, South Lampung.

Table 1. Technical data from SBP71, JIAT in South of Lampung.

\begin{tabular}{|c|c|c|}
\hline No & Component & Information \\
\hline 1 & JIAT Location & SBP 71 \\
\hline 2 & Province & Lampung \\
\hline 3 & District & Lampung Selatan \\
\hline 4 & Sub-District & Way Panji \\
\hline 5 & Village & Sidoreno \\
\hline 7 & Bench Mark Coordinate & 48 M 5648059381697 \\
\hline 8 & Control Point 1 Coordinate & 48 M 5648079381706 \\
\hline 9 & Control Point 2 Coordinate & 48 M 5648179381702 \\
\hline 10 & Year of Drilling & 1999 \\
\hline 12 & Depth of JIAT & $110 \mathrm{~m}$ \\
\hline 13 & Position of Water Elevation & $18,2 \mathrm{~m}$ \\
\hline 14 & Diameter of well & $22 \mathrm{~cm}$ \\
\hline 15 & Type of pump & Submersible \\
\hline 16 & Debit of pump & $10 \mathrm{ltr} /$ second \\
\hline 17 & Driving machine & Diesel \\
\hline 18 & Divider & 23 unit \\
\hline \multirow[t]{4}{*}{19} & Size of divider & \\
\hline & a. long & $110 \mathrm{~cm}$ \\
\hline & b. wide & $110 \mathrm{~cm}$ \\
\hline & c. hight & $55 \mathrm{~cm}$ \\
\hline 20 & Diameter of pipe & 10 \\
\hline \multirow[t]{4}{*}{21} & Dimention of Pump House & \\
\hline & a. long & $718 \mathrm{~cm}$ \\
\hline & b. wide & $315 \mathrm{~cm}$ \\
\hline & c. hight & $350 \mathrm{~cm}$ \\
\hline \multirow[t]{3}{*}{22} & Benefit & \\
\hline & Household & None \\
\hline & Irigation & 56 family \\
\hline \multirow[t]{3}{*}{23} & Planting area & \\
\hline & Secondary crops & 13 \\
\hline & Rice & 25 \\
\hline \multirow[t]{3}{*}{24} & Planting period & \\
\hline & Secondary crops & Sep-Des \\
\hline & Rice & Des - Aprl, Juni - Sep \\
\hline 25 & Produktivity & 14 ton/Ha/year of rice \\
\hline 31 & OM funder & Farmer \\
\hline 32 & Operator salary & Rp 750,000 per month \\
\hline
\end{tabular}

\subsection{Performance assessment}

Based on Ministry of Public Works and Public Housing Regulation Number 12/RT/M2015 about Exploitation and Maintenance of Irrigation System, it is stated that in order to assess JIAT's operational and maintenance performance, the things that must be considered are the performance of physical infrastructure, performance of crop productivity, performance of JIAT supporting facilities, personnel organization performance, completeness of JIAT documentation, as well as the performance of Groundwater Users (P3AT).

Assessment of the performance of physical infrastructure is carried out on:

1. Well performance is assessed based on the physical condition and function of the well to produce water in accordance with the pumping test capacity.

2. Pump performance is measured based on the physical condition and function of the pump to pump water as needed in a year.

3. The performance of the drive engine is measured by the physical condition and the ability of the engine to drive the pump according to needs.

4. The performance of the pump house is measured by the physical condition and function of the building including its facilities.

5. Channel performance is measured based on physical conditions and the function of the channel to drain water as needed.

6. The performance of complementary buildings is measured based on the physical condition of the building with functions according to planning.

The second component is cropping productivity where the previous year's productivity is calculated. Cropping productivity is compared to the average productivity that occurs in certain areas. JIAT performance related to the components of planting productivity is assessed based on 5 (five) parameters, namely:

1. Level of water needs

2. Realization of planting area

3. The level of rice productivity

4. The level of productivity of crops

5. The harvest value is compared to the costs incurred by farmers for water supply

The third component is a supporting facility, it is the facilities that support the operation and maintenance JIAT system to become effectively and efficiently. Supporting facilities assessed in the JIAT performance assessment are:

1. The well is monitored, it is necessary to measure the ground water level at all times, so that the calculation of water availability can be determined with certainty.

2. OP equipment includes basic tools for routine maintenance and personnel equipment for the operation.

3. Transportation equipment for government officials who conduct guidance and supervision and operators

4. Office equipment for the observer's office and the executor of the OP in the field.

5. Communication tools for observers and operators.

The fourth component is the personnel organization, which is the implementing organization of the OP in each well that is fully formed with personnel composition along with their job descriptions and responsibilities. The number and quality of personnel must match the needs. The duties and responsibilities of the government in managing the JIAT should only be limited to guidance 
and supervision. Therefore, the performance of the personnel organization is assessed based on the existence of the organization, the completeness of the organization, as well as the qualifications and competence of the personnel. The fifth component is the document, which consists of:

1. JIAT data book which includes technical and historical data from the JIAT development process.

2. Map of the situation of plots of land served, network schemes, and building drawings (as built drawings).

3. OP manual that has been adjusted to the last condition of the network.

The sixth component is P3AT. According to Ministry of Public Works and Public Housing Regulation Number 17/RT/M2015 concerning Irrigation Commission, what is meant by water user farmers are all farmers who benefit directly from water management and irrigation networks. Farmers in question include farmers who own rice fields, farmers who cultivate rice fields, rice paddies, fish pond owners, and business entities in agriculture that utilize irrigation water. Whereas P3AT is an irrigation management institution which is a container of waterusing farmers in a service area / tertiary plot or village that is formed democratically by water-use farmers including local irrigation management institutions.

Assessment of P3AT performance, according to Ministry of Public Works and Public Housing Regulation Number 32/RT/M2015, covering: legal institutional status, institutional development conditions, institutional activities in supporting the smooth running of the OP, and institutional participation in the implementation and financing of OP. The assessment level given in the JIAT performance evaluation results refers to the level of the assessment contained in surface water irrigation. The weighting of the JIAT Performance Index Assessment is presented in the following Table:

Table 2. Components and levels of JIAT assessment

\begin{tabular}{|c|l|l|}
\hline No & Assessment Component & Ideal Value \\
\hline 1 & physical infrastructure & 45 \\
\hline 2 & Planting productivity & 15 \\
\hline 3 & Supporting infrastructure & 10 \\
\hline 4 & Organization structure & 10 \\
\hline 5 & Documentation & 5 \\
\hline 6 & Farmer group & 15 \\
\hline & Performance Indeks & 100 \\
\hline
\end{tabular}

The results of assessment classified by four index performance:

80 - 100: Very good performance

70 - 79: Good performance

55 - 69: Poor performance and need attention

$<55$ : Worst performance and need attention

\subsection{Analysis of operation cost}

Operating costs incurred by farmers are fuel, operator wages, and light maintenance. This data is obtained from community interviews. The government cost such as operating costs other than fuel and maintenance costs for JIAT infrastructure or commonly referred to as AKNOP. JIAT infrastructures maintained include propulsion engines, pumps, pump houses, channels and networks, buildings for construction, flow measuring structures, riser pipes, road inspections, transportation equipment, and operation and maintenance equipment. Whereas activities that are operated by the government are making plans for distribution and provision of water and evaluation, monitoring and evaluation of operational activities, as well as fostering and empowering institutions and human resources.

\subsection{Economic analysis}

Economic analysis from the farmer side is useful to provide input for the government and farmers regarding the sustainability of the current policy where farmers bear JIAT operating costs. The analysis is carried out in the form of comparing the harvest value and costs incurred by farmers for the operation of the JIAT in one year.

Economic analysis from the government side is useful to provide an overview of the effectiveness of the development of JIAT. The analysis was carried out by comparing the AKNOP and the value of benefits received by farmers. Both of this analysis produce numbers of Benefit Cost Ratio (BCR).

\section{Analysis results}

This paper shows one of example for assessment proses until the complete result in SBP71 Sidoreno, South of Lampung.

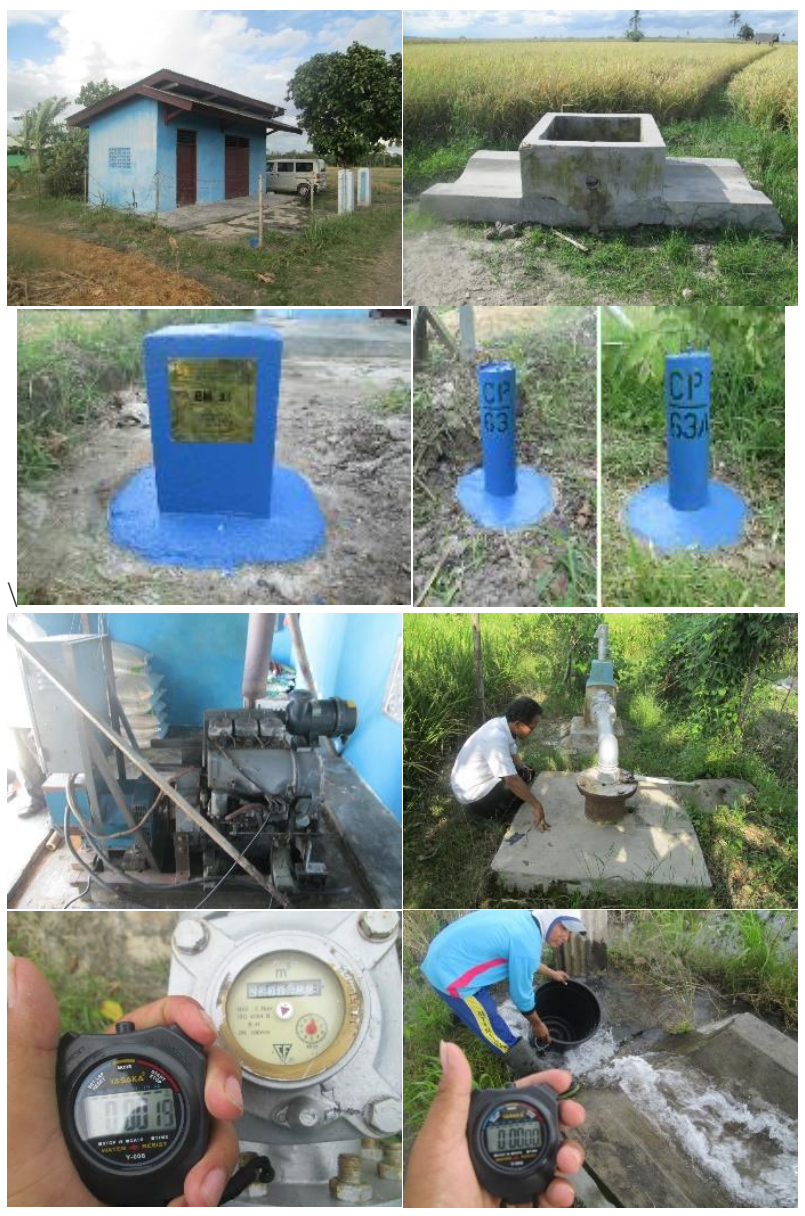

Fig. 1. The documentations of JIAT SBP71 in Sidoreno, South of Lampung 
The results of the SBP71 location performance assessment are shown in the following table.

Table 3. SBP71 assessment result

\begin{tabular}{|c|l|c|c|c|l|}
\hline No & Assessment Component & Ideal Value & Factual Value of JIAT & Performance Indeks & Information \\
\hline 1 & physical infrastructure & 45 & 35.55 & $35.55 \times 100 \%: 45=79$ & Good \\
\hline 2 & Planting productivity & 15 & 12.00 & $15 \times 100 \%: 12=80$ & Very Good \\
\hline 3 & Supporting infrastructure & 10 & 7.50 & $7.5 \times 100 \%: 10=75$ & Good \\
\hline 4 & Organization structure & 10 & 10.00 & $10 \times 100 \%: 10=100$ & Very Good \\
\hline 5 & Documentation & 5 & 0.85 & $0.85 \times 100 \%: 5=17$ & Worst performance and need attention \\
\hline 6 & Farmer group & 15 & 11.40 & $11.40 \times 100 \%: 15=76$ & Good \\
\hline & Performance Indeks & 100 & 77.30 & $77.30 \times 100 \%: 100=77.30$ & Good \\
\hline
\end{tabular}

From the performance appraisal above, the results of the SBP71 performance index were 77.30 , which means that it is a good performance category.

The next step is to calculate operating and maintenance costs by government (AKNOP), where the final results of the SBP71 AKNOP are presented in the following table:

Table 4. AKNOP (cost of operation and maintenance by government)

\begin{tabular}{|c|l|c|}
\hline No & OM Category & Total of OM Expenditure \\
\hline 1 & Maintenance of physical infrastructure & $185,971,687$ \\
\hline 2 & Maintenance of supporting infrastructure & $25,771,050$ \\
\hline 3 & Operation & $164,986,400$ \\
\hline & Total OM Expenditure (AKNOP) of SBP71 & $376,729,137$ \\
\hline
\end{tabular}

From the results above, economic analysis is calculated for the government and farmers.

For the Government:

Operating and maintenance costs per year is $\mathrm{Rp}$ $376,729,000$

Benefits received by farmers: Increase in production results due to the addition of the planting period. Before there was a JIAT, farmers only relied on one period of rice planting during the rainy season, but after there was a JIAT, farmers could apply the Rice-Rice-Palawija pattern. The BCR obtained is: 1.34

\section{For Farmers:}

The annual operating and maintenance costs incurred by 1 farmer are Rp 51,840,000

Farmer's income in one year is $\mathrm{Rp} 114,000,000$.

The BCR obtained is: 2.22

This step is applied to all JIAT locations in Lampung Province. Recapitulation of results is shown in the table below. Some locations are in a very bad state because the JIAT infrastructures were totally gone, so it cannot asses or it is given a zero value $(0 /-)$.

Table 5. Recapitulation of JIAT performance in Lampung Province.

\begin{tabular}{|c|l|r|r|c|c|}
\hline No. & JIAT & $\begin{array}{c}\text { Perfor } \\
\text { mance } \\
\text { Index }\end{array}$ & AKNOP & $\begin{array}{c}\text { BCR } \\
\text { Gov }\end{array}$ & $\begin{array}{c}\text { BCR } \\
\text { Farm }\end{array}$ \\
\hline 1 & SBP 1 & 0 & - & - & - \\
\hline 2 & SBP 2 & 0 & - & - & - \\
\hline
\end{tabular}

\begin{tabular}{|c|c|c|c|c|c|}
\hline No. & JIAT & $\begin{array}{l}\text { Perfor } \\
\text { mance } \\
\text { Index }\end{array}$ & AKNOP & $\begin{array}{l}\text { BCR } \\
\text { Gov }\end{array}$ & $\begin{array}{l}\text { BCR } \\
\text { Farm }\end{array}$ \\
\hline 3 & SBP 3 & 0 & - & - & - \\
\hline 4 & SBP 6 & 0 & - & - & - \\
\hline 5 & SBP 7 & 0 & - & - & - \\
\hline 6 & SBP 8 & 0 & - & - & - \\
\hline 7 & SBP 11 & 0 & - & - & - \\
\hline 8 & SBP 12 & 0 & - & - & - \\
\hline 9 & SBP 15 & 0 & - & - & - \\
\hline 10 & SBP 18 & 0 & - & - & - \\
\hline 11 & SBP 19 & 0 & - & - & - \\
\hline 12 & SBP 20 & 0 & - & - & - \\
\hline 13 & SBP 21 & 0 & - & - & - \\
\hline 14 & SBP 27 & 0 & - & - & - \\
\hline 15 & SBP 29 & 0 & - & - & - \\
\hline 16 & SBP 31 & 0 & - & - & - \\
\hline 17 & SBP 33 & 0 & - & - & - \\
\hline 18 & SBP 34 & 0 & - & - & - \\
\hline 19 & SBP 35 & 0 & - & - & - \\
\hline 20 & SBP 38 & 0 & - & - & - \\
\hline 21 & SBP 51 & 0 & - & - & - \\
\hline 22 & SBP 52 & 0 & - & - & - \\
\hline 23 & SBP 53 & 0 & - & - & - \\
\hline 24 & SBP 54 & 0 & - & - & - \\
\hline 25 & SBP 55 & 0 & - & - & - \\
\hline 26 & SBP 56 & 0 & - & - & - \\
\hline 27 & SBP 57 & 0 & - & - & - \\
\hline 28 & SBP 58 & 0 & - & - & - \\
\hline 29 & SBP 59 & 0 & - & - & - \\
\hline 30 & SBP 60 & 0 & - & - & - \\
\hline 31 & SBP 61 & 0 & - & - & - \\
\hline 2 & SBP 62 & 0 & - & - & - \\
\hline 33 & SBP 63 & 0 & - & - & - \\
\hline 34 & SBP 64 & 0 & - & - & - \\
\hline 35 & SBP 72 & 0 & - & - & - \\
\hline 36 & SBP 75 & 0 & - & - & - \\
\hline 37 & SBP 33 & 0 & - & - & - \\
\hline 38 & SBP 94 & 0 & - & - & - \\
\hline 39 & SBP 104 & 0 & - & - & - \\
\hline 40 & SBP 5 & 0 & - & - & - \\
\hline 41 & SBP 111 & 0 & - & - & - \\
\hline 42 & SBP 26 & 0 & - & - & - \\
\hline 43 & PPS 1 & 0 & - & - & - \\
\hline 44 & SBP 13 & 0 & - & - & - \\
\hline 45 & SBP 24 & 0 & - & - & - \\
\hline 46 & PPS2 & 0 & - & - & - \\
\hline 47 & SBE 5P & 52.30 & $381,956,533$ & 1.34 & 1.86 \\
\hline 48 & SBE 23 & 37.53 & $353,094,913$ & 1.34 & 1.34 \\
\hline 49 & SBP 10 & 51.33 & $349,389,223$ & 1.34 & 1.86 \\
\hline 50 & SBP 65 & 37.13 & $331,648,863$ & 1.35 & 1.34 \\
\hline 51 & SBP 67 & 51.73 & $309,831,063$ & 1.35 & 1.86 \\
\hline 52 & SBP 74 & 36.30 & $304,886,293$ & 1.35 & 1.34 \\
\hline 53 & SBP 76 & 32.70 & $299,941,523$ & 1.35 & 1.34 \\
\hline 54 & SBP 78 & 51.25 & $339,763,263$ & 1.35 & 1.86 \\
\hline 55 & SBP 82 & 57.05 & $330,144,663$ & 1.35 & 1.86 \\
\hline 56 & SBP 86 & 47.75 & $330,144,663$ & 1.35 & 1.55 \\
\hline
\end{tabular}




\begin{tabular}{|c|c|c|c|c|c|}
\hline No. & JIAT & $\begin{array}{l}\text { Perfor } \\
\text { mance } \\
\text { Index }\end{array}$ & AKNOP & $\begin{array}{l}\text { BCR } \\
\text { Gov }\end{array}$ & $\begin{array}{l}\text { BCR } \\
\text { Farm }\end{array}$ \\
\hline 57 & SBP 91 & 32.30 & $326,839,563$ & 1.35 & 1.34 \\
\hline 58 & SBP 98 & 46.55 & $326,839,563$ & 1.35 & 1.55 \\
\hline 59 & SBP 107 & 37.40 & $269,127,963$ & 1.38 & 1.34 \\
\hline 60 & SBP 90 & 35.85 & $326,079,183$ & 1.35 & 1.34 \\
\hline 61 & SBP 95 & 46.35 & $326,079,183$ & 1.35 & 1.55 \\
\hline 62 & SBP 103 & 59.95 & $363,636,573$ & 1.34 & 1.86 \\
\hline 63 & SBE 36 & 33.45 & $366,387,603$ & 1.34 & 1.34 \\
\hline 64 & SBP 101 & 48.75 & $245,462,343$ & 1.38 & 1.55 \\
\hline 65 & SBP 50 & 25.45 & $259,890,243$ & 1.38 & 1.20 \\
\hline 66 & SBP 83 & 72.30 & $229,206,903$ & 1.38 & 2.22 \\
\hline 67 & SBE 21 & 74.50 & $367,122,223$ & 1.34 & 2.22 \\
\hline 68 & SBE 39 & 74.50 & $309,831,063$ & 1.35 & 2.22 \\
\hline 69 & SBE 40 & 84.25 & $366,584,713$ & 1.34 & 2.50 \\
\hline 70 & SBE 42 & 74.60 & $331,244,963$ & 1.35 & 2.22 \\
\hline 70 & SBP 4 & 66.10 & $364,223,533$ & 1.34 & 2.00 \\
\hline 71 & SBP 9 & 78.92 & $334,554,913$ & 1.35 & 2.22 \\
\hline 72 & SBP 16P & 75.85 & $319,720,603$ & 1.35 & 2.22 \\
\hline 73 & SBP 23 & 85.65 & $322,030,263$ & 1.35 & 2.50 \\
\hline 74 & SBP 36 & 80.45 & $317,220,963$ & 1.35 & 2.50 \\
\hline 75 & SBP 66 & 78.55 & $388,947,383$ & 1.34 & 2.22 \\
\hline 76 & SBP 68 & 81.85 & $324,665,373$ & 1.35 & 2.50 \\
\hline 77 & SBP 69 & 83.75 & $369,168,303$ & 1.34 & 2.50 \\
\hline 78 & SBP 71 & 77.30 & $374,113,073$ & 1.34 & 2.22 \\
\hline 79 & SBP 79 & 73.30 & $346,076,763$ & 1.35 & 2.22 \\
\hline 80 & SBP 80 & 68.05 & $346,076,763$ & 1.35 & 2.00 \\
\hline 81 & SBP 84 & 81.55 & $326,839,563$ & 1.35 & 2.50 \\
\hline 82 & SBP 85 & 81.40 & $339,763,263$ & 1.35 & 2.50 \\
\hline 83 & SBP 96 & 77.50 & $360,504,663$ & 1.35 & 2.22 \\
\hline 84 & SBP 97 & 75.70 & $346,076,763$ & 1.35 & 2.22 \\
\hline 85 & SBP 100 & 75.30 & $317,220,963$ & 1.35 & 2.22 \\
\hline 86 & SBP 102 & 81.25 & $322,030,263$ & 1.35 & 2.50 \\
\hline 87 & SBP 110 & 77.45 & $326,839,563$ & 1.35 & 2.22 \\
\hline 88 & SBE 34 & 67.60 & $279,052,693$ & 1.35 & 2.00 \\
\hline 89 & SBE 35 & 81.85 & $352,951,463$ & 1.35 & 2.50 \\
\hline 90 & SBP 89 & 73.70 & $339,515,323$ & 1.35 & 2.22 \\
\hline 91 & SBP 80 & 73.20 & $440,286,373$ & 1.30 & 2.22 \\
\hline 92 & SBE 29P & 75.95 & $279,052,693$ & 1.38 & 2.22 \\
\hline 93 & SBE 30 & 73.15 & $272,334,623$ & 1.38 & 2.22 \\
\hline 94 & SBP 81 & 67.45 & $272,334,623$ & 1.38 & 2.00 \\
\hline 95 & SBP 88 & 68.75 & $386,541,813$ & 1.34 & 2.00 \\
\hline 96 & SBP 93 & 69.35 & $406,696,023$ & 1.30 & 2.00 \\
\hline 97 & SBP 105 & 73.85 & $326,079,183$ & 1.35 & 2.22 \\
\hline 98 & SBP 87 & 68.30 & $305,924,973$ & 1.35 & 2.00 \\
\hline 99 & SBP 99 & 74.55 & $366,387,603$ & 1.34 & 2.22 \\
\hline 101 & SBE 38 & 70.00 & $305,924,973$ & 1.35 & 2.22 \\
\hline 102 & SBP 108 & 68.25 & $305,924,973$ & 1.35 & 2.00 \\
\hline 103 & SBP 109 & 73.75 & $363,636,573$ & 1.34 & 2.22 \\
\hline 104 & SBP 92 & 71.00 & $366,387,603$ & 1.34 & 2.22 \\
\hline 105 & SBP 106 & 75.25 & $359,669,533$ & 1.34 & 2.22 \\
\hline 106 & SBP 115 & 75.35 & $332,797,253$ & 1.35 & 2.22 \\
\hline 107 & SBE 9P & 81.05 & $352,287,913$ & 1.34 & 2.50 \\
\hline 108 & SBE 19 & 79.10 & $391,846,073$ & 1.33 & 2.22 \\
\hline 109 & SBE 32 & 79.35 & $337,453,603$ & 1.35 & 2.22 \\
\hline 110 & SBP 14 & 79.35 & $401,885,113$ & 1.30 & 2.22 \\
\hline 111 & SBP 70 & 81.65 & $299,941,523$ & 1.35 & 2.50 \\
\hline 112 & SBP 77 & 80.75 & $334,554,913$ & 1.35 & 2.50 \\
\hline
\end{tabular}

\section{Conclusions}

The conclusions obtained from the analysis above are:

1. 46 JIAT locations were not operating and the infrastructure was heavily damaged or totally gone (performance index was not asses or got zero).

2. 20 JIAT locations usually were run, but the main infrastructure had been damaged during the research (performance index 55-69).
3. 39 locations were run and the infrastructures were in a good condition/ slightly damaged (performance index 70-79).

4. 6 JIAT locations just rehabilitated so the conditions were excellent (performance index $>79$ ).

5. The BCR value for the government is not always directly related with the performance index value, but is closely related to the AKNOP value. The bigger the AKNOP, the lower the BCR. However, of all JIAT locations that are still operating, all BCR numbers show results $>1$, which means that JIAT development deserves to be continued economically.

6. The BCR value for farmers is certainly not related to AKNOP, but is directly proportional to the performance index. The smaller the performance index, the smaller the BCR number. However, of all JIAT operating locations, all BCR figures show $>1$ results, which means that the use of JIAT in 66 locations is worthy of being continued economically even though the fuel costs and other routine operations are borne by the farmers.

\section{Recommendations}

Suggestions that can be submitted from the results of this study are:

1. The government should always carry out the obligation of maintenance according to the budget that has been prepared (AKNOP) so that JIAT's performance is always maintained.

2. By seeing the benefits, in the future can be built more JIAT in locations that need it.

3. For farmers, even though it is quite heavy to issue JIAT operating costs, but if seen in its entirety, farmers still benefit economically, so the selfmanagement fee policy for JIAT operations should not be used as an excuse to ignore the infrastructure already built by the Government. This policy is also good enough to foster awareness of mutual cooperation and mutual ownership with Farmers.

\section{References}

1. Ministry of Public Works and Public Housing Regulation Number 12/RT/M2015

2. Ministry of Public Works and Public Housing Regulation Number 17/RT/M2015

3. Ministry of Public Works and Public Housing Regulation Number 32/RT/M2015

4. Achmad Nifan El Wafi, Moch. Sholichin, Ussy Andawayanti, Kajian Ekonomi Sumur Dalam PKB111 pada Irigasi Air Tanah di Desa Kaliakah Kecamatan Negara Kabupaten Jembrana Provinsi Bali, 10.

5. Muhammad Arifudin Nugraha, Rini Wahyu Sayekti, Riyanto Haribowo, Studi Evauasi Jaringan Irigasi Air Tanah di Desa Panggungsari Kecamatan Durenan Kabupaten Trenggalek, 10.

6. B.M. Sinaga, Sumaryanto, Estimasi Nilai Ekonomi Air Irigasi dan Strategi Pemanfaatannya dalam Penentuan Iuran Irigasi, 19. 